ANZTLA

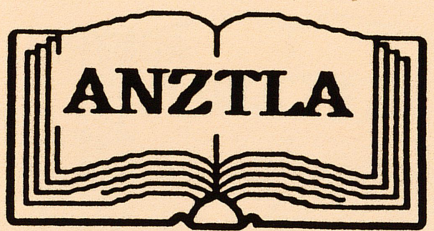

NEWSLETTER

GIBSON - RADCLIFFE

MEMORIAL LIBRARY

EMMANUEL COLLEGE
No 37

April 1999 


\section{AUSTRALIAN AND NEW ZEALAND THEOLOGICAL LIBRARY ASSOCIATION}

ANZTLA is an association of libraries and individuals involved and interested in theological librarianship. It seeks to co-operate with Australian and New Zealand Association of Theological Schools and to promote its aims and objectives insofar as they apply to libraries and librarianship. However, membership is open to all libraries and individuals sharing the interests of the Association, upon payment of the prescribed fee.

The ANZTLA Newsletter is published three times a year to provide a means of communication between members and interested persons.

Contributions are invited of relevant articles and items of interest to theological librarianship; scholarly articles. information on all aspects of librarianship; book reviews; library profiles; and news about libraries and librarians. Articles should be typed, and submitted to the editor in hard copy (for scanning).

ANZTLA holds an annual conference, in association with the conference of the Australian and New Zealand Association of Theological Schools where practicable. Local Chapters of the Association in the major cities provide a forum for local interaction.

ISSN: $1030-701 \mathrm{X}$

President:

Vice President

Secretary:

Treasurer:

Editor:

Executive Member:

\begin{abstract}
Kim Robinson, Moore Theological College 1 King Street, Newtown NSW 2042

Phone: $0295779880 \quad$ Fax: 0295779898 email: library@moore.edu.au
\end{abstract}

Philip Harvey, Joint Theological Library

Ormond College, Parkville Vic 3052

email: Philip.Harvey@ormond.unimelb.edu.au

Stephen Connelly, Joint Theological Library

Phone: $0393478480 \quad$ Fax: 0393491857

email: Stephen.Connelly@ormond.uinmelb.edu.au

Lynn Pryor, Churches of Christ Theological College

P O Box 629, Mulgrave North Vic 3170

Phone: $0397901000 \quad$ Fax 0397951688

email: PRYORL@wva.org.au

Lynn Pryor

Beth Prior, Adelaide Theological Library, 34 Lipsett Terrace, Brooklyn Park, SA 5032

Phone: 08 Fax: 0884168410

Email: Beth.Prior@flinders.edu.au

ANZTLA Membership and Subscription to the Newsletter:

Association membership (inc Newsletter subscription) \$A40 p.a.

Newsletter only

\$A20 p.a.

Overseas surcharge

\$A5 p.a.

Payment to Treasurer

Some back issues available from the Editor ( $\$ 7.00$ each) 


\section{ANZTLA NEWSLETTER}

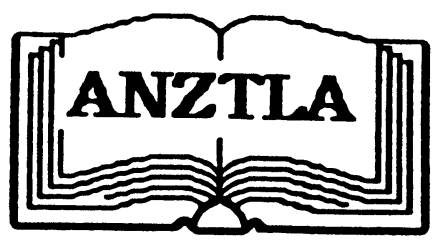

\section{Contents}

Reference resources 1998 / Rhonda Barry

Site insight :

Lawrence and Pamela McIntosh visit the Pacific 8

ANZTLA statistics 1997 / compiled by Helen Greenwood 11

The division of the Gillespie Divinity Library

/ Catherine Halsall

New Norcia and Freedom of Information

/ Susan Johnson

Notes from the MCD / Stephen Connelly

ANZTLA Standards : update

\section{No 37




\title{
Reference resources 1998
}

\author{
Rhonda Barry
}

\begin{abstract}
Biblical Studies
Bibliographie zu Ben Sira. Gemeinsam mit Nuria Calduch-Benages ... [et al]; herausgegeben von Friedrich Vinzenz Reiterer (Beihefte zur Zeitschrift fur die alttestamentliche Wissenschaft; Bd. 266). Berlin: de Gruyter, 1998. $3110161362 \$ 200.00$ Bibliography of the apocryphal book Ecclesiasticus.
\end{abstract}

Briggs, Constance Victoria. The encyclopedia of angels. New York: Plume, 1997. $0452279216 \$ 18.99$.

Entries are short - from a few lines to a paragraph at most. Includes a 5 page bibliography.

Dictionary of the later New Testament and its developments. Editors, Ralph P. Martin and Peter H. Davids. Downers Grove, Ill.: InterVarsity Press, 1997. 0830817794\$45.00.

Companion volume to the Gospels and Pauline Epistles. Covers the remaining books of the New Testament canon. Same style and format as the earlier volumes in this very useful set.

Enns, Peter. Poetry and wisdom. (IBR bibliographies; no.3). Grand Rapids, Mich.: Baker Books, 1997. $081021618 \$ 16.95$.

Bibliography of Hebrew poetry and wisdom literature. Index of authors. Each citation has a short (2-7 lines) comment.

Finegan, Jack. Handbook of Biblical chronology: principles of time reckoning in the ancient world and problems of chronology in the Bible. Rev. ed. Peabody, Mass.: Hendrickson, 1998. $1565631439 \$ 45.00$.

The international Bible commentary: a Catholic and ecumenical commentary for the twenty-first century. Editor, William R. Farmer. Collegeville, Minn.: Liturgical Press, 1998. $0814624545 \$ 200.00$.

Richards, Larry. Illustrated Bible handbook. Nashville, Tenn.: T. Nelson, 1997. $0785212485 \$ 29.00$

Thompson, Henry 0. The book of Amos: an annotated bibliography. (ATLA bibliography series; no.42) Lanham, Md.: Scarecrow Press, 1997. 0810832747 \$147.00.

Alphabetical bibliography with author, scripture and subject indexes. Also lists separately dissertations and journals.

Thompson, Henry 0. Zechariah: a bibliography. Delhi: ISPCK, 1996. 8172141238 $\$ 3.50$.

Scripture, subject and author indexes, but no annotations. 


\section{Theology}

APS guide to resources in theology

URL: http://www.utoronto.ca/stmikes/theobook.htm

This web site is maintained by the Faculty of Theology at the University of Toronto.

A dictionary of early Christian beliefs : a reference guide to more than 700 topics discussed by the Early Church Fathers. Editor, David Bercot. Peabody, Mass.: Hendrickson, 1998. $1565633571 \$ 39.95$.

Functions as an index to the writings of the Ante-Nicene writers. Begins with a short who's who. Covers theological, moral and historical topics. Entries are alphabetical by topic and comprise quotations from the Fathers.

Miller, Ed L. Fortress introduction to contemporary theologies. Minneapolis, Minn.: Fortress Press, 1998. $0800629817 \$ 29.95$.

Contemporary means the last 100 years. There are short (1-2 page) overviews of topics under various theologians, for example, Bonhoeffer, religionless Christianity; Cobb, Process theology; Bultmann, demythologization; Gutierrez, salvation as liberation.

\section{Christian Church}

Anglican religious communities year book 1999. Norwich: Canterbury Press, 1998. $1853112062 \$ 15.00$.

Gives a short description of the community, list of staff, facilities, publications, address and contact numbers.

Brierley, P. W. Atlas of world Christianity : 2000 years. Singapore: OM Publishing; London: Christian Research, 1998. 1853211281 (Christian Research) \$40.00.

Covers geographic areas as well as topics, such as church growth, missions, world religions. Comprises mainly maps and statistics.

Bunson, Matthew. Our Sunday Visitor's encyclopedia of saints. Huntington, Ind.: Our Sunday Visitor Publishing Division, 1998. $0879735880 \$ 89.95$.

Alphabetical order of entries. Includes entries on canonisation, and includes beati honoured as martyrs or significant historical figures, for example, Blessed Edith Stein. There are appendices covering Vatican documents, canonised popes, emblems, martyrs of USA, patron saints.

Cohn-Sherbok, Lavinia. Who's who in Christianity. London: Routledge, 1998. $041535826 \$ 38.00$.

Short biographies with a few bibliographic citations after each person. Includes a glossary and a chronology of chief historical events.

Utter, Glenn H. The religious right: a reference handbook. (Contemporary world issues) Santa Barbara, Calif.: ABC-CLIO, 1995. $0874367786 \$ 59.00$. 
Looks at the religious right and its role in American life in legislation and society. Includes an historical survey of the movement, biographies, annotated lists of print and non-print resources, organisations and a bibliography.

\section{Religions}

Academic info religion: a directory of Internet resources for the study of religion URL: http://www.academicinfo.net/religindex.html

A subject based directory still under development.

Donzel, E. J. van. The Encyclopaedia of Islam, new edition. Index of proper names to volumes I-LX and to the supplement, fascicules 1-6. 6th ed. Boston: Brill, 1998. 9004110828

A guide to the best religious studies resources on the Internet.

URL: http://www.freenet.edmonton.ab.ca/-cstier/religion/toc.htm

Designed to provide useful introductory Internet links to resources of the world's major religious traditions. From the University of Alberta.

Judaism and Jewish resources

URL : http://www.shamash.org/trb/judaism.html

The work of Andrew Tannenbaum, this is one of the most complete directories of links to Jewish resources on the web, covering several hundred sites. Includes Jewish organisations, libraries and Jewish book sellers.

Parker, Philip M. Religious cultures of the world: a statistical reference (Cross-cultural statistical encyclopedia of the world; v.1) Westport, Conn.: Greenwood Press, 1997. $0313297681 \$ 70.00$.

\section{Church History}

Blevins, Carolyn DeArmond. Women in Christian history: a bibliography. Macon, Ga.: Mercer University Press, 1995. 086554493X \$65.00.

Coverage is from the earliest church to present times and all branches of the Christian church.

Dictionary of heresy trials in American Christianity. Edited by George H. Shriver. Westport, Conn.: Greenwood Press, 1997. 031329660X

Presents the stories of 50 formal and informal heresy trials. Arranged alphabetically by person or institution. Includes index and bibliography.

Kery, Lotte. Canonical collections of the early Middle Ages (ca. 400-1140): a bibliographical guide to the manuscripts and literature. (History of medieval canon law; v.1) Washington, D.C.: Catholic University of America Press, 1998. 0813209188 $\$ 88.00$. 


\section{Missions}

Biographical dictionary of Christian missions. Edited by Gerald H. Anderson. New York: Macmillan Reference USA, 1997. $0028646045 \$ 145.00$.

Articles on 2400 persons across all Christian denominations from the early church to the present day. Appendices include a chronological listing and listing by type of work, geographical region, denomination.

Dictionary of mission: theology, history, perspectives. Edited by Karl Muller ... [et al.] (American Society of Missiology series; no.24) Maryknoll, N.Y.: Orbis Books, 1997. $157075148 \mathrm{X}$

Entries are from a few to several pages in length with bibliography. Covers theology as well as mission topics such as human rights, African independent churches, development, apocalyptic and mission, Orthodox mission.

\section{Languages and Linguistics}

Bretzke, James T. Consecrated phrases: a Latin theological dictionary: Latin expressions commonly found in theological writings. Collegeville, Minn.: Liturgical Press, 1998. $\$ 50.00$.

A consecrated phrase refers to an expression that is used to express a certain theological position or thought, such as ex opere operato. Entries are rather short, gives first a literal translation of the phrase and then a brief gloss on the theological significance of the term. Designed for quick consultation.

Hatch, Edwin. A concordance to the Septuagint and the other Greek versions of the Old Testament (including the Apocryphal books). 2nd ed. Grand Rapids, Mich.: Baker Books, 1998. $0801021413 \$ 175.00$.

Kohlenberger, John R. The Hebrew-English concordance to the Old Testament. Grand Rapids, Mich.: Zondervan, 1998. $0310208394 \$ 200.00$.

Headings in Hebrew or Aramaic and transliterated into English. Context is the NIV. Exhaustive index to the vocabulary of the Hebrew OT according to Biblia Hebraica Stuttgartensia, 4th ed. 1990.

Muraoka, T. Hebrew/Aramaic index to the Septuagint: keyed to the Hatch-Redpath concordance. Grand Rapids, Mich.: Baker Books, 1998. $0801021456 \$ 40.00$.

\section{Philosophy}

Cambridge history of seventeenth-century philosophy. Edited by Daniel Garber, Michael Ayers. Cambridge: Cambridge University Press, 1998. 2 vols. 0521307635 (v.1) 0521588642 (v.2) $\$ 280.00$.

Topical arrangement. A review noted that the entries were indepth. Bibliographies included. Recommended for graduate researchers and faculty. 
A companion to continental philosophy. Edited by Simon Critchley and William Schroeder. (Blackwell companions to philosophy). Oxford: Blackwell, 1998. $0631190139 \$ 135.00$.

Contributes to the study of continental philosophy in English speaking countries. Covers persons, movements, criticism. An introductory article sketches themes in continental philosophy.

One hundred twentieth-century philosophers. Edited by Stuart Brown, Diane Collinson, Robert Wilkinson. London: Routledge, 1998. $0415179963 \$ 30.00$.

Entries were chosen for their wide impact on twentieth-century thought. Also a guide to schools and movements.

Routledge encyclopedia of philosophy. General editor, Edward Craig. London: Routledge, 1998. 10 vols. $\$ 5000.00$.

9 volumes and index (v.10). Vol. 5 contains a glossary of logical and mathematical terms. Three types of entry: signposts which provide a general overview of the topic; thematic; biographical.

\section{Miscellaneous}

Australian feminism: a companion. General editor, Barbara Caine. Melbourne: Oxford University Press, 1998. $0195538188 \$ 79.95$.

Covers feminist theory, politics and scholarship, feminist involvement in facets of government and welfare. Includes history and nature of Australian feminism, expression in the arts, major publications and organisations.

The C. S. Lewis readers' encyclopedia. Edited by Jeffrey D. Schultz and John G. West, Jr. Grand Rapids, Mich.: Zondervan, 1998. $0310215382 \$ 39.95$.

Also provides links to other literary and philosophical works. Bibliographies throughout .

The complete book of everyday Christianity: an A-to-Z guide to following Christ in every aspect of life. Edited by Robert Banks and R. Paul Stevens. Downers Grove, Ill.: InterVarsity Press, 1997. $0830814507 \$ 30.00$.

Deals with issues relating to everyday life such as boredom, church structures, empty nesting, gardening, public transportation and simpler life styles.

The directory of publishers in religion. Compiled by Mike Farry. (Scholars Press handbook series) Atlanta, Ga.: Scholars Press, 1997. 07885041OX

The little book of style. Compiled by Shirley Purchase. Canberra: AusInfo, Dept. of Finance and Administration, 1998. 0644382961 \$9.95. AGPS cat. no. 9700803.

Matsunami, Kodo. International handbook of funeral customs. Westport, Conn.: Greenwood Press, 1998. $0313304432 \$ 120.00$ 
Covers the current cultural and religious customs concerning death, burial and mourning in the world and covers the major religions.

Thody, Philip. Don't do it !: a dictionary of the forbidden. New York: St Martin's Press, 1997. $0312173733 \$ 40.00$.

Covers five sections on actions; nourishment; words and themes; ideas, books and pictures; signs.

Rhonda Barry

Assistant Librarian

Moore Theological College, Sydney.

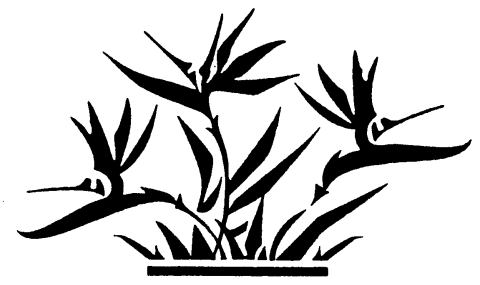

\section{ANZTLA assists theological libraries in South Pacific}

At ANZTLA's 1997 AGM, members decided to donate $\$ 2000$ to the South Pacific Association of Theological Schools (SPATS) for their library support programme. Our colleague, Jeanette Little, who has for several years been the librarian at Pacific Theological College in Suva, has been appointed as Library Consultant to SPATS.

In this role Jeanette is based in Suva, but about $50 \%$ of her time will involve travelling throughout the Pacific region. She will visit theological libraries, for two or three weeks at a time, assisting library staff in any practicable way - from rearranging furniture to evaluating collections, cataloguing the backlog, or assisting with selection and ordering of new materials.

It is anticipated that our contribution to the funding of this consultancy will be used for the purchase of essential books - both librarian's tools and theological texts to enhance collections. When she becomes more settled in her new role, we hope that Jeanette will give us a fuller picture of what her consultancy involves.

Compiled by Lynn Pryor 


\section{Site insight: \\ Lawrence and Pamela McIntosh visit Pacific theological colleges May 1998}

\section{Lawrence McIntosh}

Our journey to Western Samoa and the Kingdom of Tonga was sponsored by the Commission on Education for Ministry of the Uniting Church in Australia. The intention of this honorary consultancy was to visit three colleges - Piula Theological College (Methodist) and Malua Theological College (Congregational) in Western Samoa, and Sia'atoutai Theological College (Methodist) in Tonga. Each college has a rich heritage of ministry-oriented studies; in two cases dating some one hundred and fifty years. We also paid a delightful visit to the Catholic Theological College at Maomao in Western Samoa.

Arriving in Samoa on the $6^{\text {th }}$ May, we spent a week in Piula and a second week at Malua. We were in Tonga from the $19^{\text {th }}$ to the $26^{\text {th }}$ May.

We understood our mission to be one of listening, observing, offering advice, and generally drawing attention to library principles and practices as they appeared appropriate to a particular college. In each venue we worked through a Library survey which we had designed as a means of data gathering and generally reviewed the library's facilities, staffing requirements, collections and services. Discussions were held with library staff about perceptions of library services and the use of resources. In the Samoan colleges it was possible to meet members of the faculties and to discuss the inadequacies of resources for teaching purposes. In Tonga, given that our visit coincided with a vacation period, it was not possible to do this. With each library having quite different needs, we spent time in supporting staff in whatever job priorities made most sense. Pamela, also a librarian, variously assisted by reviewing donated items, revising the classification, and tutoring in technical-services processing.

Upon our return home, we prepared separate reports for the principals which summarised our conversations and observations. I suspect that these reports are limited by the constraints of time spent at each college and, in all likelihood, by a failure to adequately interpret all positions and perspectives. It is clear however that the colleges, having decided upon expanded degree programs, need to develop staff participation, augment resources and increase services.

We appreciated the cordial welcome and generous cooperation of many colleagues and were grateful also for the delightful accommodation and hospitality. The spontaneous friendship was indeed precious. We trust that our visits and reporting have helped clarify certain library issues and that our recommendations, including the lengthy lists of suggested reference works, monographs and serials, will assist in the further development of these very special libraries.

In response to a number of questions asked at the conference in July, I should add the following thoughts on ways in which ANZTLA may assist these Pacific libraries. 
- I have recommended to each library that it becomes a member of ANZTLA and, if this eventuates, we should remember 'the Pacific presence', particularly in the Newsletter.

- The Australasian religion index could well index the contents of scholarly Polynesian serials, in addition to the Journal of the Polynesian society.

- Certain ANZTLA libraries may be willing to host members of the staffs of these libraries, for brief periods, and provide them with experience of library management, services and resources.

- Now for a negative. With regard to these libraries and others like them, we should cease sending cast-off material that is outdated, inaccurate, dilapidated or otherwise unacceptable. Pamela and I discovered piles of material, donated by American and Australian libraries, which were cluttering up library space and amounting to a millstone around the librarian's neck. (The silliest pile was that donated by an American college which had somehow confused 'technology' with 'theology', and sent out their outdated college texts on engineering!)

What to do? Following conversations with a particular library, we could profitably send duplicates of current publications, in relevant subject areas. But please, not junk.

- and, finally, we should, periodically, seek the advice of Jeanette Little, ANZTLA's expert in the area, concerning ways in which we could be of use to Pacific libraries.

Our colleagues in these islands are among the most gracious and courteous people imaginable. Their hospitality is legendary. It is our privilege to be with them and learn from them.

Lawrence D. McIntosh

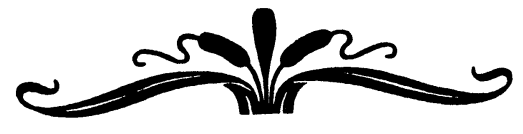

\section{Directory of Australian Special Libraries}

Do you wish to be included in the $10^{\text {th }}$ edition of this directory (due to be published early 1999)? It may be too late! But if you're really keen, you might contact Barbara Eames, the Editor.

Barbara, a self-employed consultant who has worked in Special Libraries in Victoria for many years, was appointed Editor for the $10^{\text {th }}$ edition of DASL (Directory of Australian Special Libraries) by the National Committee Special Libraries Section. She would appreciate hearing from you, and welcomes any information regarding Special Libraries that have moved, changed names, or may need to be removed from the Directory.

The DASL Editor can be contacted at Box 3091, Syndal Vic 3149. 


\title{
Oral, Print \& Digital Cultures: Bound Together in Theological Libraries
}

\author{
AUSTRALIAN \& NEW ZEALAND \\ THEOLOGICAL LIBRARY \\ ASSOCIATION \\ Fourteenth Annual Conference
}

\author{
Luther Seminary \\ 104 Jeffcott Street, North Adelaide \\ South Australia \\ Thursday 1st July - Sunday 4th July \\ 1999
}

\section{Some highlights}

\section{Thursday Ist July}

- Keynote address : Cross-cultural challenges and choices of using information and knowledge, in the past, present, future. Dr Marion Maddox

Friday 2nd July

- Workshops on cataloguing; marketing of services; information literacy; professional development; preservation issues.

- ANZTLA AGM

- Evening address : Archaeology of the Holy Land Dr Michael Trainor

Saturday 3rd July

- Reference tools for theological librarians - print and electronic.

- McLaren Vale tour: wines, almonds, olives, cheeses! Galleries!

- Conference Dinner at the Waterfall Gully Restaurant

Sunday 4th July

- Tools for personal reflection

- Practicalities

If you have not received a conference brochure and would like to register, please contact Val Canty at the Adelaide Theological Library phone 08 8416 8417; fax 0884168410 ; or email

val.canty@flinders.edu.au SOON for details!

Registration by $30^{\text {th }}$ April would be appreciated - to assist with accommodation 


\section{ANZTLA STATISTICS}

\section{7}

compiled by Helen Greenwood

Preliminary notes :

In calculating averages and medians, the NAs have been disregarded.

\section{KEY TO TABLES :}

\{\}$=$ calculations made by statistician

[ ] = approximations supplied by library

STAFF SALARIES 1997

\begin{tabular}{|c|c|c|c|c|c|}
\hline Scale & Category A & Category B & Categony $\mathrm{C}$ & Category D & TOTAL \\
\hline Protessional & 11 & 3 & 2 & 2 & 18 \\
\hline Church salary & 1 & 1 & 0 & 0 & 2 \\
\hline Others & 3 & 6 & 1 & 0 & 10 \\
\hline Not specified & 12 & 8 & 6 & 2 & 28 \\
\hline
\end{tabular}




\section{AUTOMATION 1997}

\begin{tabular}{|c|c|}
\hline System & No or Illoraries \\
\hline Ameritech & 1 \\
\hline Automated, not specified & 4 \\
\hline Bookmark: & 4 \\
\hline Catalist & 3 \\
\hline CS Library & 1 \\
\hline DB Text 2.1 & 2 \\
\hline DRAUNilinc & 2 \\
\hline Dynix & 6 \\
\hline Dynix Scholar & 1 \\
\hline Inmagic & 1 \\
\hline Inmagic Plus & 3 \\
\hline Library PRO & 1 \\
\hline Metamarc & 2 \\
\hline Microfusion & 1 \\
\hline Not automated & 2 \\
\hline Oasis & 9 \\
\hline Ocelot & 1 \\
\hline Semi-automated & 2 \\
\hline Urica 2000 & 2 \\
\hline
\end{tabular}

COMPUTER PRODUCTS 1997

\begin{tabular}{|c|c|}
\hline Produal & No of Libraies \\
\hline OVID & 1 \\
\hline CD-Roms & 10 \\
\hline Catholic periodical Index & 2 \\
\hline ATLA Religion indexes & 21 \\
\hline Internet access & 19 \\
\hline $\begin{array}{l}\text { Catechism of the Catholic } \\
\text { Church }\end{array}$ & 2 \\
\hline NRSV & 1 \\
\hline 20:21 Library & 4 \\
\hline Encarta & 3 \\
\hline Encyclopaedia Britannica & 5 \\
\hline Logos 2 & 2 \\
\hline Gramchord & 1 \\
\hline NZBN & 3 \\
\hline Hebrew tutorial & 5 \\
\hline Koorong Connection & 2 \\
\hline Reformation Library & 1 \\
\hline Master Christian Library & 1 \\
\hline Theological Journal Library & 1 \\
\hline Dead Sea Scrolls revealed & 2 \\
\hline Sage Digital Library & 3 \\
\hline $\mathrm{ABN}$ & 6 \\
\hline LCSH & 1 \\
\hline Bible Dictionary & 1 \\
\hline Bible Atlas & 1 \\
\hline Quick verse for Windows & 1 \\
\hline National Geographic & 1 \\
\hline 1991 Australian census & 1 \\
\hline $\begin{array}{l}\text { Religious \& Theological } \\
\text { Abstracts }\end{array}$ & 9 \\
\hline Justice \& Equity & 1 \\
\hline World religions & 1 \\
\hline Greek tutor & 3 \\
\hline INNZ & 1 \\
\hline Logos Bible & 1 \\
\hline Holy land explorer & 1 \\
\hline Austrom & 2 \\
\hline Sydney Morning Herald index & 1 \\
\hline Old Testament Abstracts & 2 \\
\hline Religious groups in Australia & 1 \\
\hline Book of Concord & 1 \\
\hline Thesaurus Linguae Graecae & 2 \\
\hline CD-word & 1 \\
\hline Bible Library & 1 \\
\hline Macquarie Dictionary & 1 \\
\hline Karl Barth. Kirche Dogmatik & 1 \\
\hline $\begin{array}{l}\text { CETEDOC Library of Christian } \\
\text { Latin texts }\end{array}$ & 1 \\
\hline Early Church fathers & 1 \\
\hline CD-Bible & 1 \\
\hline Age issues in the news & 1 \\
\hline
\end{tabular}


TABLE 1A 1997 LIBRARY STAFF

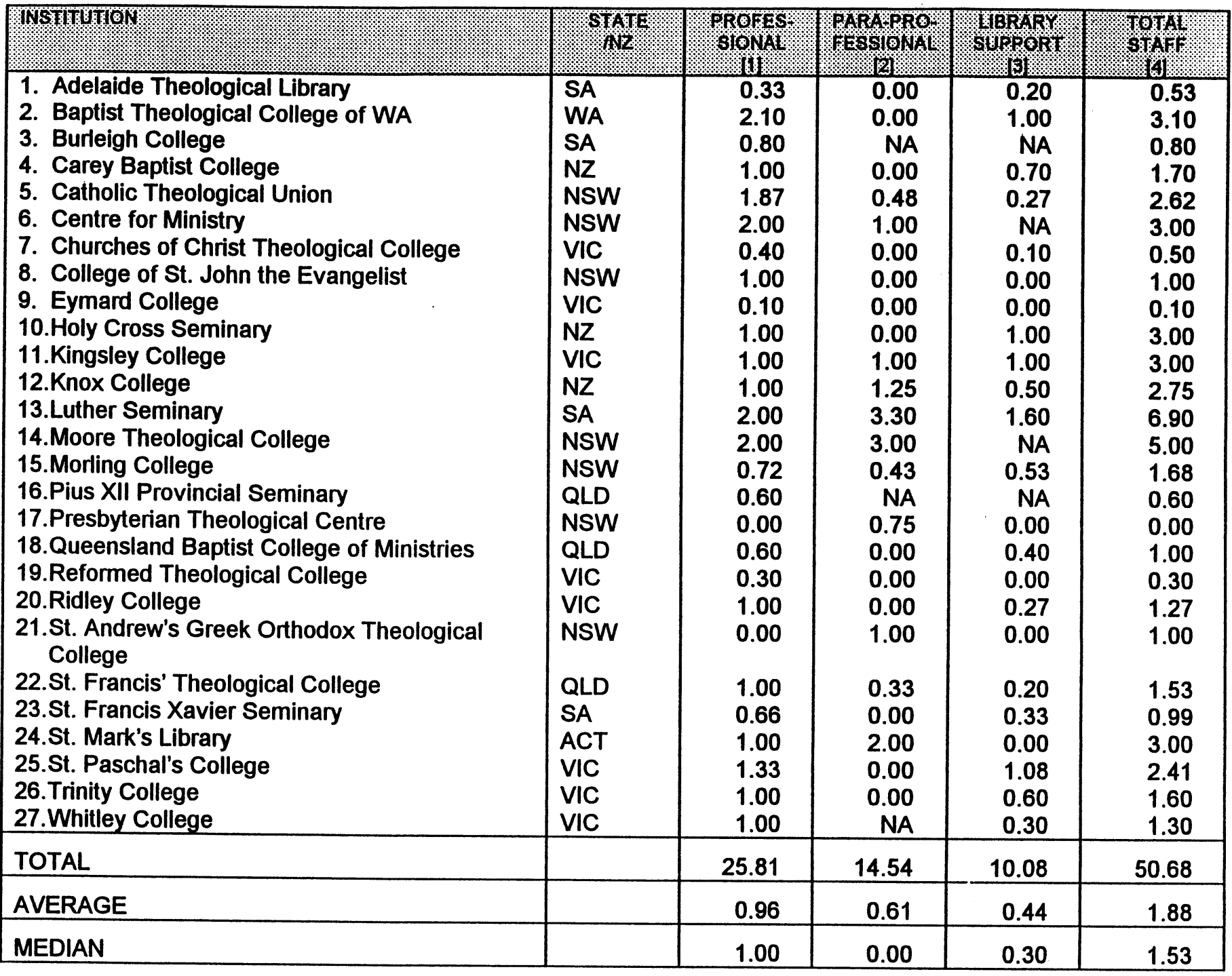

TABLE 1B 1997 LIBRARY STAFF

\begin{tabular}{|c|c|c|c|c|c|}
\hline INSTITUTION : : : : : : : : : : : : : & $\begin{array}{l}\text { STATE } \\
\text { INZ }\end{array}$ & 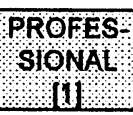 & $\begin{array}{l}\text { PARAPRO } \\
\text { FESSIONAL }\end{array}$ & $\begin{array}{l}\text { GBRARY } \\
\text { SUPPORT }\end{array}$ & STTAL \\
\hline 1. Bible College of New Zealand & NZ & 1.00 & 0.00 & 0.80 & 1.80 \\
\hline 2. Bible College of Queensland & QLD & 0.30 & 0.00 & 0.60 & 0.90 \\
\hline 3. Bible College of Victoria & VIC & 1.00 & 0.00 & 0.80 & 1.80 \\
\hline 4. Canberra College of Theology & ACT & 1.00 & 0.00 & 6.00 & 7.00 \\
\hline 5. Emmaus Bible College & NSW & 0.00 & 1.00 & 1.00 & 2.00 \\
\hline 6. Grace College of Ministry & SA & NA & 1.00 & 0.40 & 1.40 \\
\hline 7. Kenmore Christian College & QLD & 0.00 & 0.75 & 0.25 & 1.00 \\
\hline 8. New Creation Library & SA & 0.00 & 0.00 & 2.00 & 2.00 \\
\hline 9. Nungalinya College & NT & 0.60 & 0.00 & 0.40 & 1.00 \\
\hline 10.Perth Bible College & WA & 0.00 & 0.50 & 0.00 & 0.50 \\
\hline 11.Salvation Army Training College & NZ & 0.38 & 0.00 & 0.05 & 0.43 \\
\hline 12.Strikeforce Ministry Training Institute & QLD & 0.00 & 0.00 & 0.50 & 0.50 \\
\hline 13.Sydney Missionary and Bible College & NSW & 0.00 & 0.60 & 1.50 & 2.10 \\
\hline 14. Tabor College (SA) & SA & 1.00 & NA & 0.35 & 1.35 \\
\hline 15. Tabor College (Vic.) & VIC & 0.00 & 0.33 & 1.10 & 1.43 \\
\hline 16. Tahlee Bible College & NSW & NA & 0.33 & 1.50 & 1.88 \\
\hline 17.Vianney College & NSW & 0.60 & 0.00 & 0.00 & 0.60 \\
\hline 18. Worldview Centre for Intercultural Studies & TAS & 0.33 & 1.00 & 1.00 & 2.33 \\
\hline TOTAL & & 6.21 & 5.51 & 18.25 & 30.02 \\
\hline AVERAGE & & 0.39 & 0.32 & 1.01 & 1.67 \\
\hline MEDIAN & & 0.30 & 0.00 & 0.60 & 1.40 \\
\hline
\end{tabular}


TABLE 1C 1997 LIBRARY STAFF

\begin{tabular}{|c|c|c|c|c|c|}
\hline TNSTITGTIONY & STATE & $\begin{array}{l}\text { PROFESP } \\
\text { STINAT }\end{array}$ & 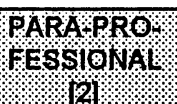 & 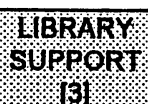 & $\begin{array}{l}\text { TOGALI: } \\
\text { STAFr' }\end{array}$ \\
\hline $\begin{array}{l}\text { 1. Carmelite Library } \\
\text { 2. Catholic Education Office } \\
\text { 3. Columban Mission Institute } \\
\text { 4. Diocesan Resource Centre } \\
\text { 5. Mollison Library } \\
\text { 6. New Norcia Library } \\
\text { 7. Rabbi Falk Library } \\
\text { 8. St. Benedict's Monastery }\end{array}$ & $\begin{array}{l}\text { VIC } \\
\text { QLD } \\
\text { NSW } \\
\text { SA } \\
\text { VIC } \\
\text { WA } \\
\text { NSW } \\
\text { NSW }\end{array}$ & $\begin{array}{l}0.40 \\
1.00 \\
0.15 \\
1.00 \\
0.50 \\
1.50 \\
0.50 \\
0.20 \\
\end{array}$ & $\begin{array}{r}0.20 \\
\text { NA } \\
0.50 \\
0.80 \\
\text { NA } \\
0.00 \\
0.00 \\
0.75 \\
\end{array}$ & $\begin{array}{r}0.20 \\
\text { NA } \\
0.00 \\
1.00 \\
\text { NA } \\
0.00 \\
0.33 \\
0.00 \\
\end{array}$ & $\begin{array}{l}0.80 \\
1.00 \\
0.65 \\
2.80 \\
0.50 \\
1.50 \\
0.83 \\
0.95 \\
\end{array}$ \\
\hline TOTAL & & 5.25 & 2.25 & 1.53 & 9.03 \\
\hline AVERAGE & & 0.66 & 0.38 & 0.26 & 1.13 \\
\hline MEDIAN & & 0.50 & 0.20 & 0.00 & 0.83 \\
\hline
\end{tabular}

TABLE 1D 1997 LIBRARY STAFF

\begin{tabular}{|c|c|c|c|c|c|}
\hline GNSTITHTON & STATE & $\begin{array}{l}\text { PROFES: } \\
\text { SIONAY } \\
\text { MU1 }\end{array}$ & $\begin{array}{l}\text { PARAPPRO. } \\
\text { FESSIONAY } \\
|2|\end{array}$ & SUBRARY. & STAFT \\
\hline $\begin{array}{l}\text { 1. Australian Catholic University - McAuley } \\
\text { Campus } \\
\text { 2. Australian Catholic University - Mt. St. Mary's } \\
\text { Campus } \\
\text { 3. Australian Catholic University - Signadou } \\
\text { Campus } \\
\text { 4. Catholic Library of WA }\end{array}$ & $\begin{array}{l}\text { QLD } \\
\text { NSW } \\
\text { ACT } \\
\text { WA }\end{array}$ & $\begin{array}{l}4.40 \\
6.33 \\
3.00 \\
2.00\end{array}$ & $\begin{array}{l}6.00 \\
6.00 \\
1.60 \\
1.40\end{array}$ & $\begin{array}{l}3.80 \\
2.33 \\
1.50 \\
1.80\end{array}$ & $\begin{array}{r}14.20 \\
14.66 \\
6.10 \\
5.20\end{array}$ \\
\hline TOTAL & & 15.73 & 15.00 & 9.43 & 40.16 \\
\hline AVERAGE & & 3.93 & 3.75 & 2.36 & 10.04 \\
\hline MEDIAN & & 3.00 & 1.60 & 1.80 & 6.10 \\
\hline
\end{tabular}




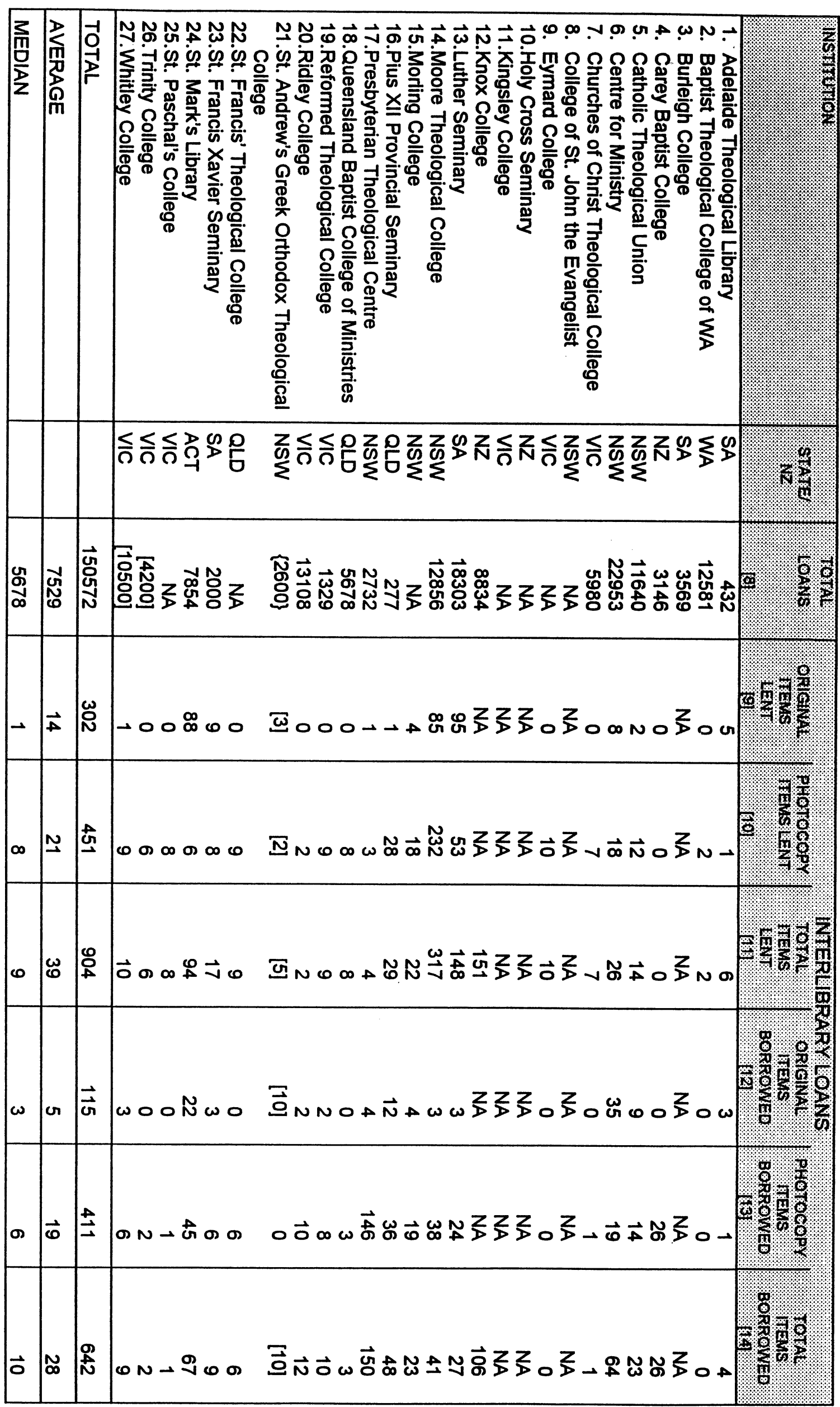




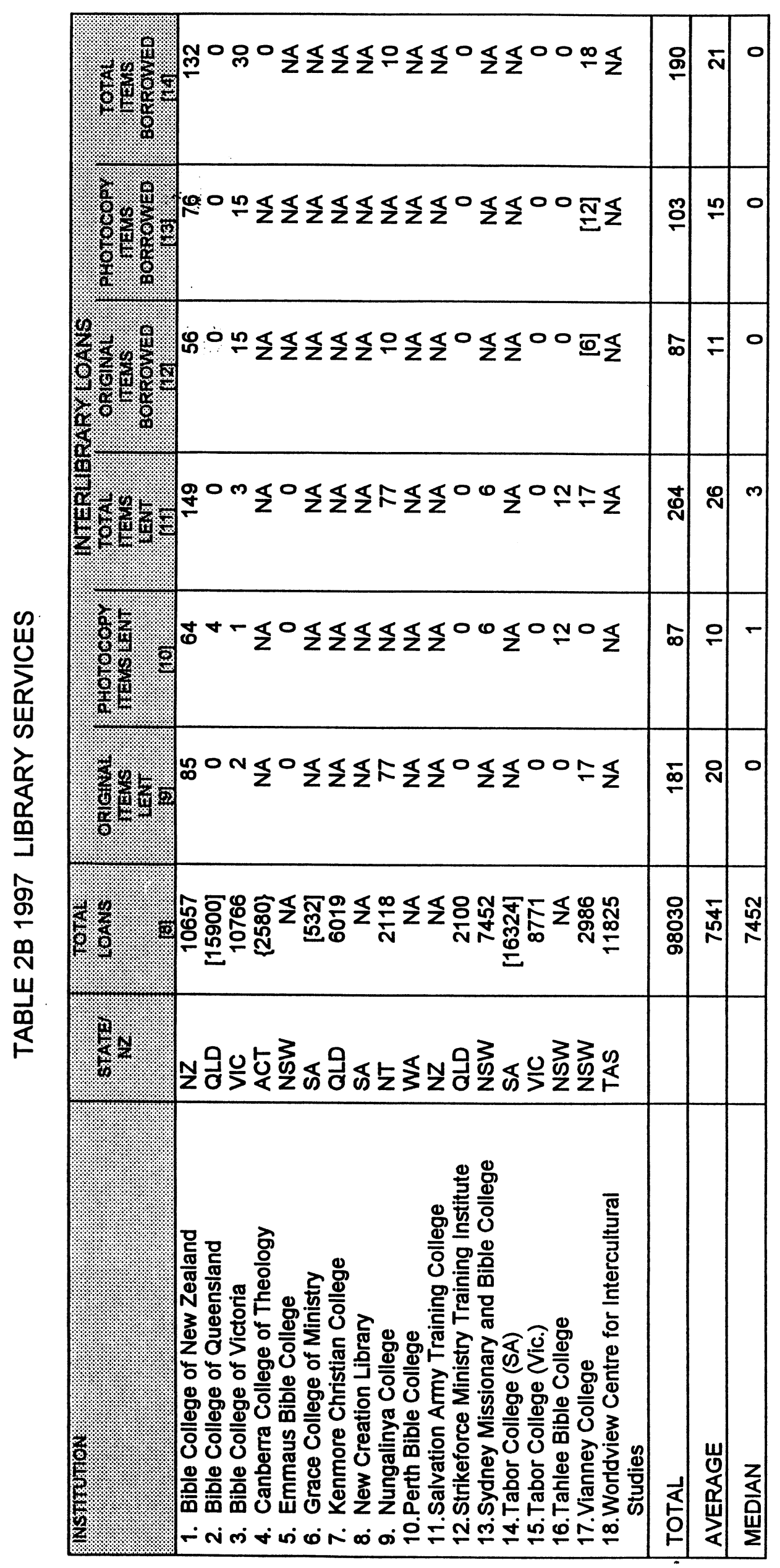




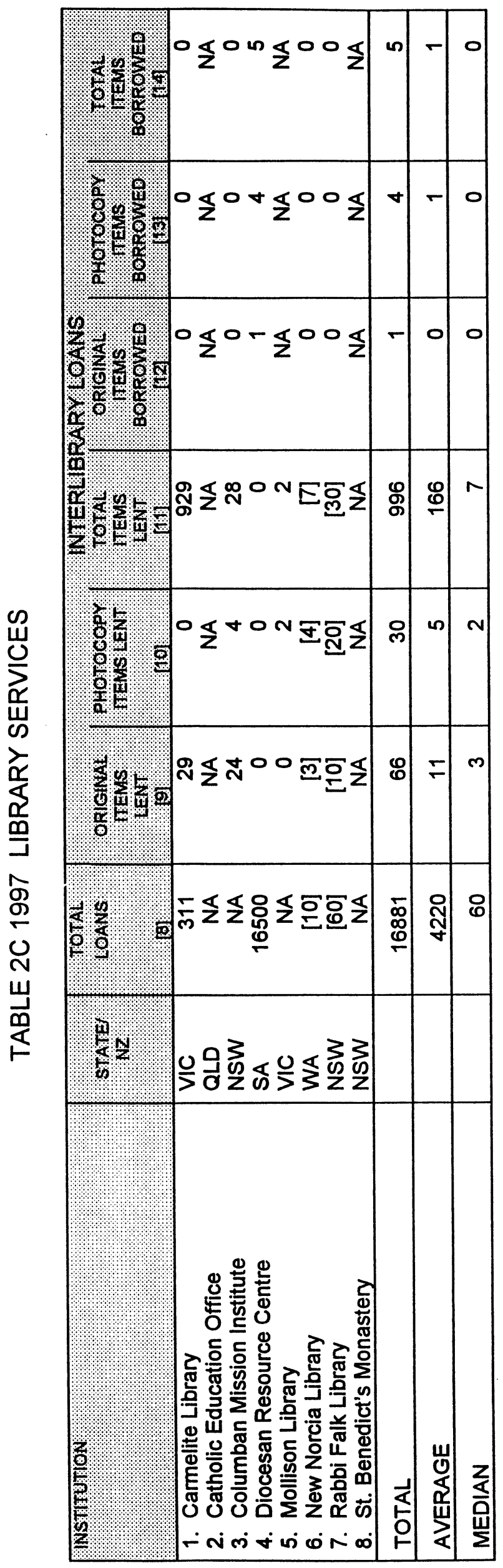

\begin{tabular}{|c|c|c|c|c|c|c|c|}
\hline 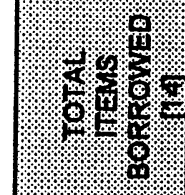 & $\frac{\sqrt[S]{+}}{2}$ & $\stackrel{\check{N}}{\stackrel{\infty}{*}}$ & $\Phi$ & 0 & ঙ্ֶু & m్ల & 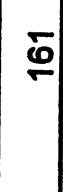 \\
\hline 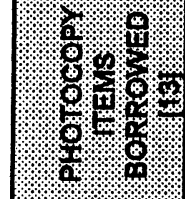 & 응 & $\stackrel{\text { స్ }}{\sim}$ & 요 & 이 & $\stackrel{9}{\frac{9}{v}}$ & ర్లి & 유 \\
\hline 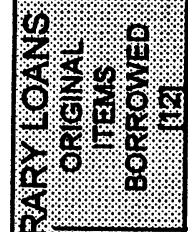 & f & $\stackrel{8}{\circ}$ & $F$ & 이 & $\frac{+}{\pi}$ & $\stackrel{R}{\sim}$ & $F$ \\
\hline 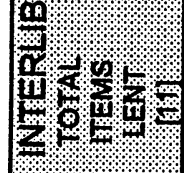 & $\stackrel{\mathcal{N}}{\mathscr{N}}$ & $\underset{m}{\stackrel{\infty}{\infty}}$ & $\stackrel{\circ}{\infty}$ & 이 & $\stackrel{\infty}{\infty}$ & जी & $\stackrel{\circ}{\circ}$ \\
\hline 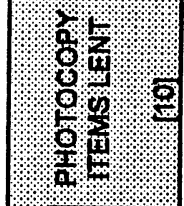 & $\stackrel{\mathscr{O}}{\stackrel{2}{2}}$ & ஜ & $\mathscr{Y}$ & 이 & 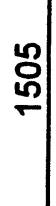 & $\begin{array}{l}0 \\
\stackrel{m}{m}\end{array}$ & $\mathcal{F}$ \\
\hline 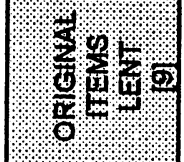 & ఖ్ల & $\stackrel{\Re}{\stackrel{n}{\sim}}$ & $\stackrel{\infty}{\stackrel{m}{\sim}}$ & 이 & $\begin{array}{l}\boldsymbol{n} \\
\boldsymbol{0}\end{array}$ & 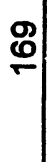 & 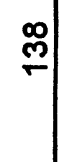 \\
\hline 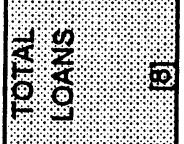 & $\underset{\substack{\infty \\
\infty ্ \infty}}{\infty}$ & $\underset{\substack{\frac{0}{5} \\
\text { in }}}{2}$ & $\Sigma$ & స̃ & $\frac{n}{\sigma}$ & 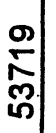 & $\frac{0}{\frac{1}{5}}$ \\
\hline$\frac{a}{4} \frac{1}{6}$ & 号 & $\frac{3}{2}$ & 过 & $\$$ & & & \\
\hline 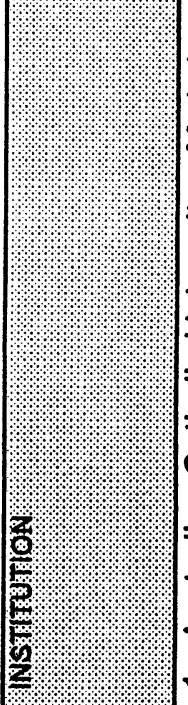 & 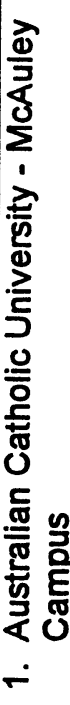 & 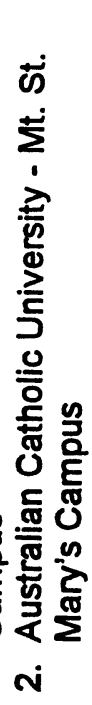 & 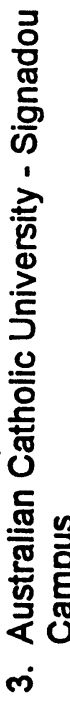 & 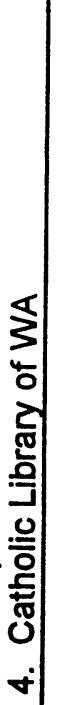 & $\begin{array}{l}\frac{1}{5} \\
5 \\
0 \\
\end{array}$ & 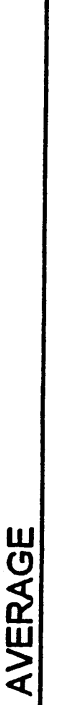 & 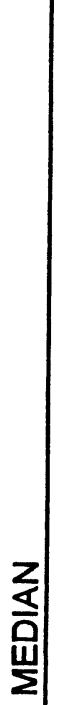 \\
\hline
\end{tabular}




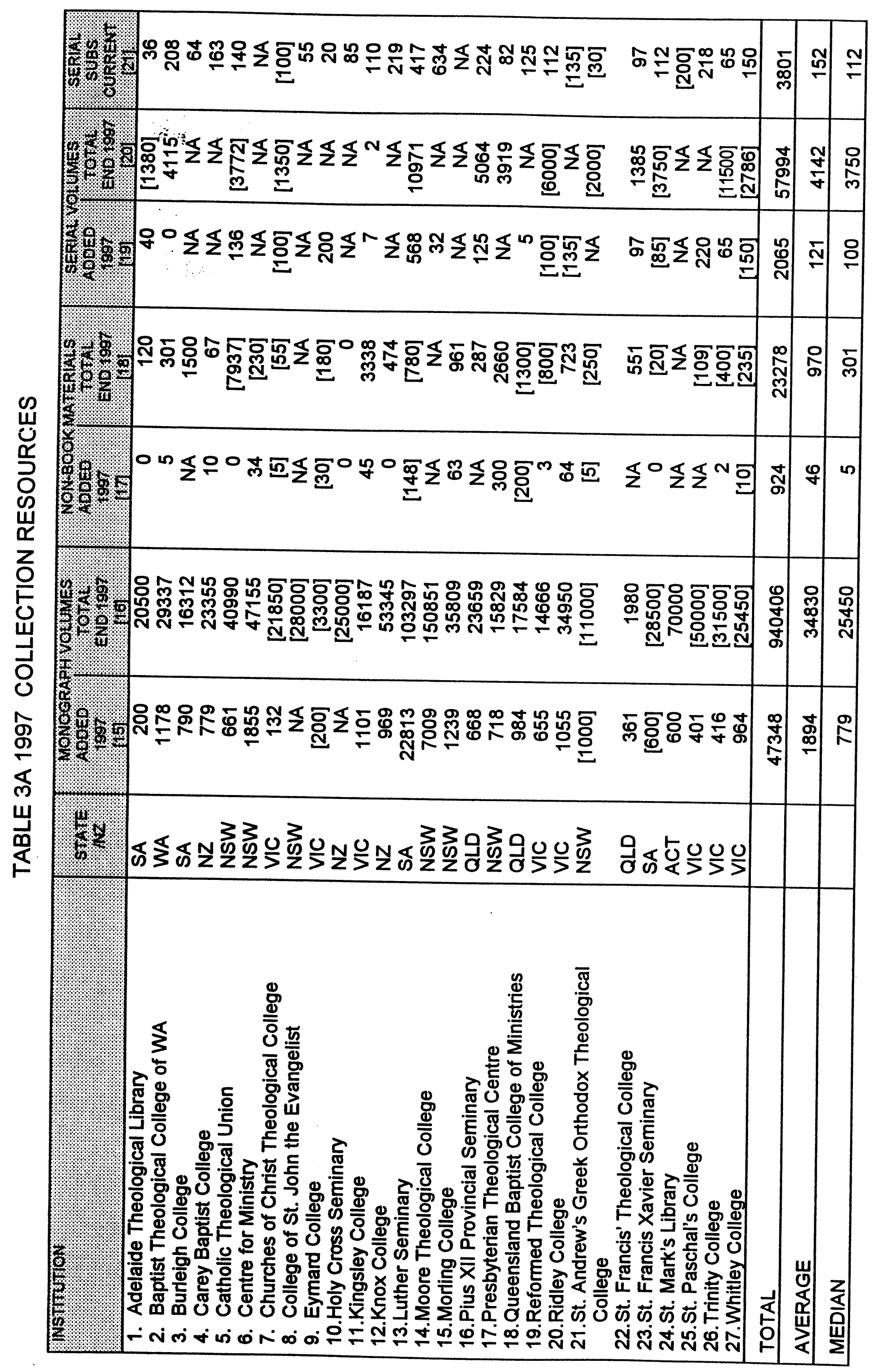




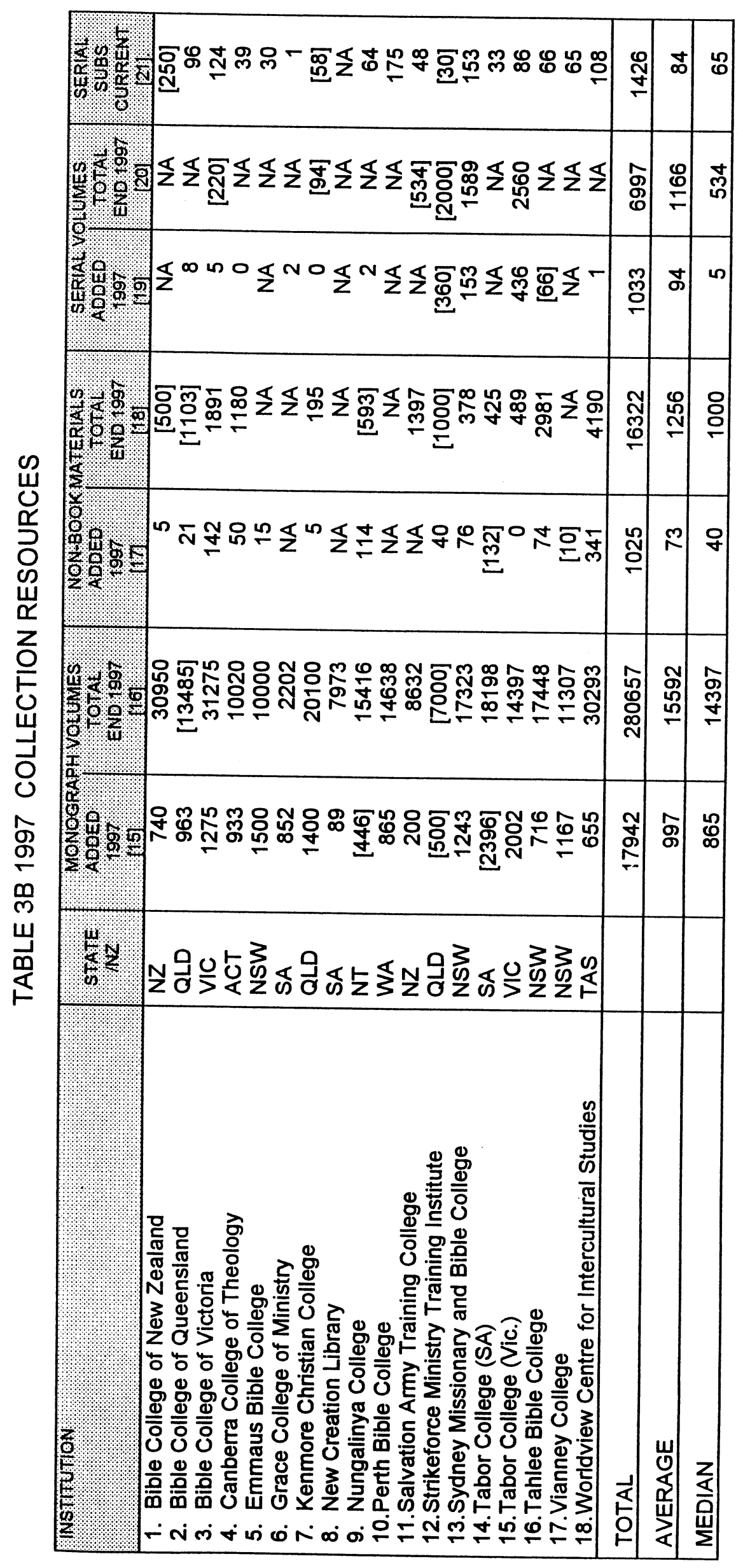




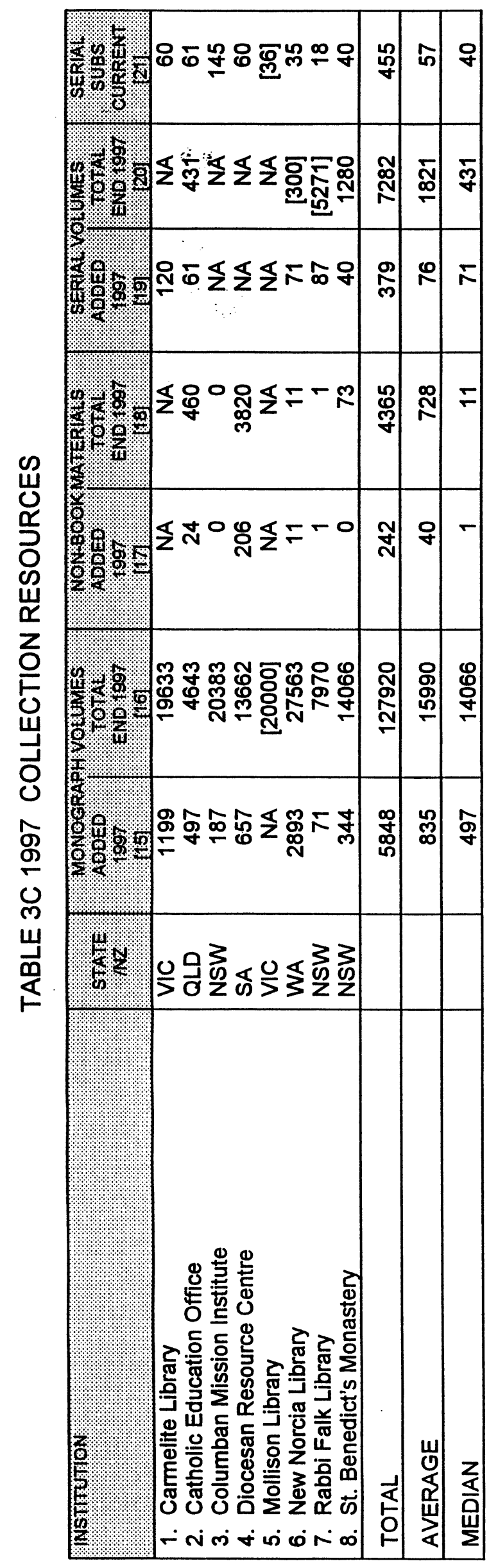

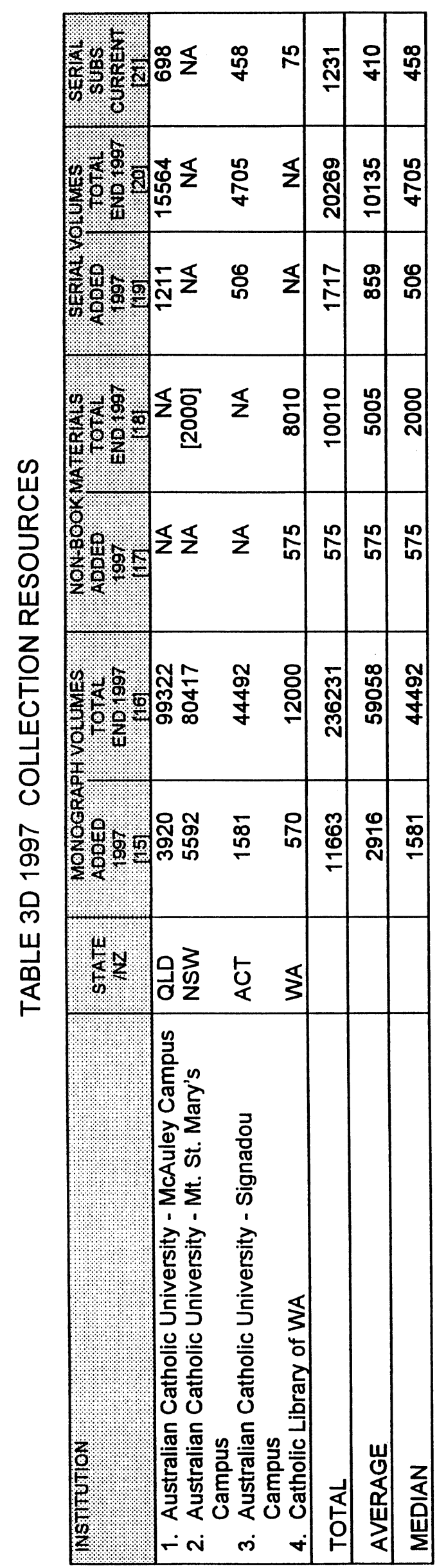


TABLE 4A 1997 LIBRARY EXPENDITURE

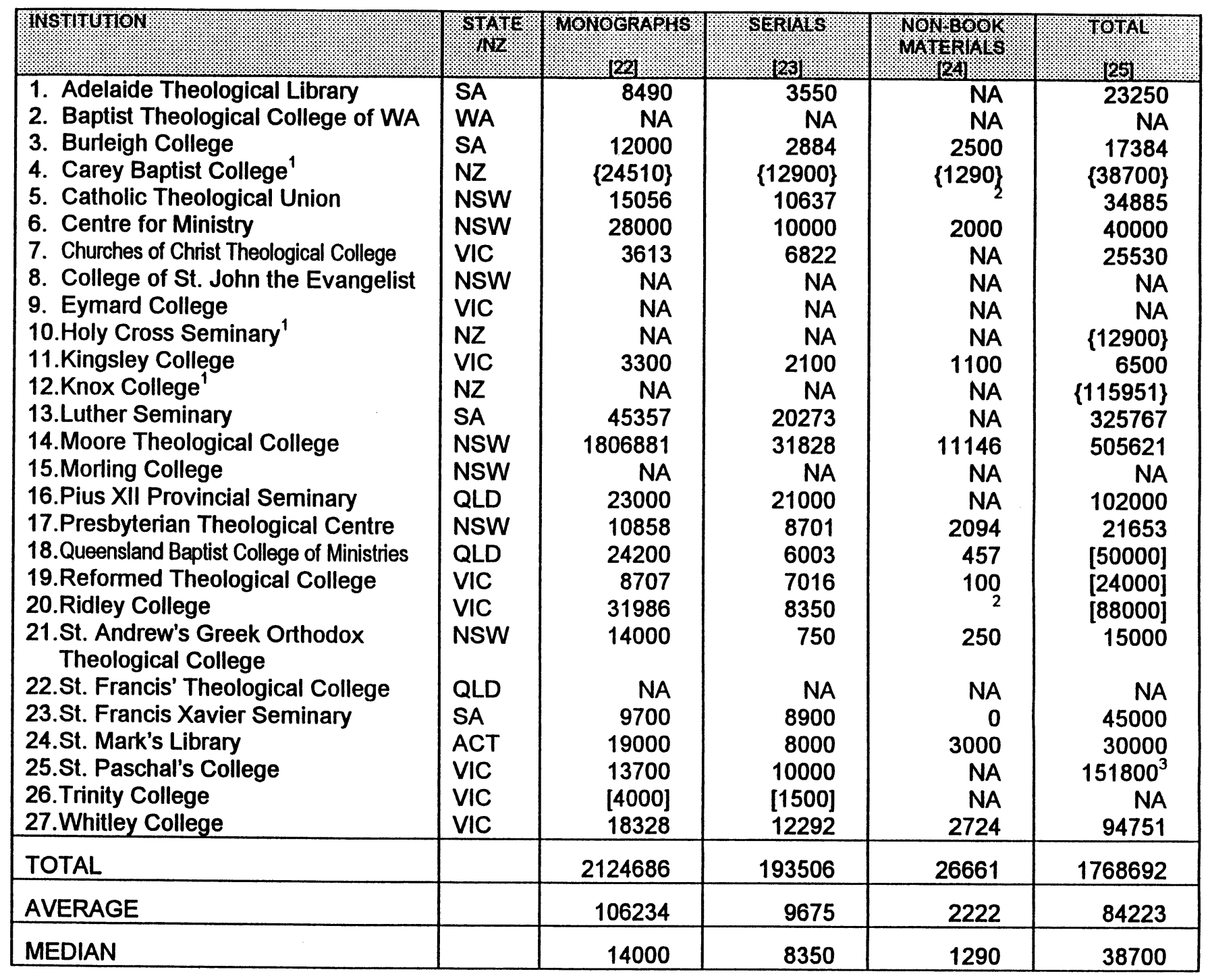

\footnotetext{
${ }_{2}^{1}$ Exchange rate $=0.86$

2 Included in monograph expenditure

${ }^{3}$ Financial year Feburary 1997-January1998; includes expenses relating to automation
} 
TABLE 4B 1997 LIBRARY EXPENDITURE

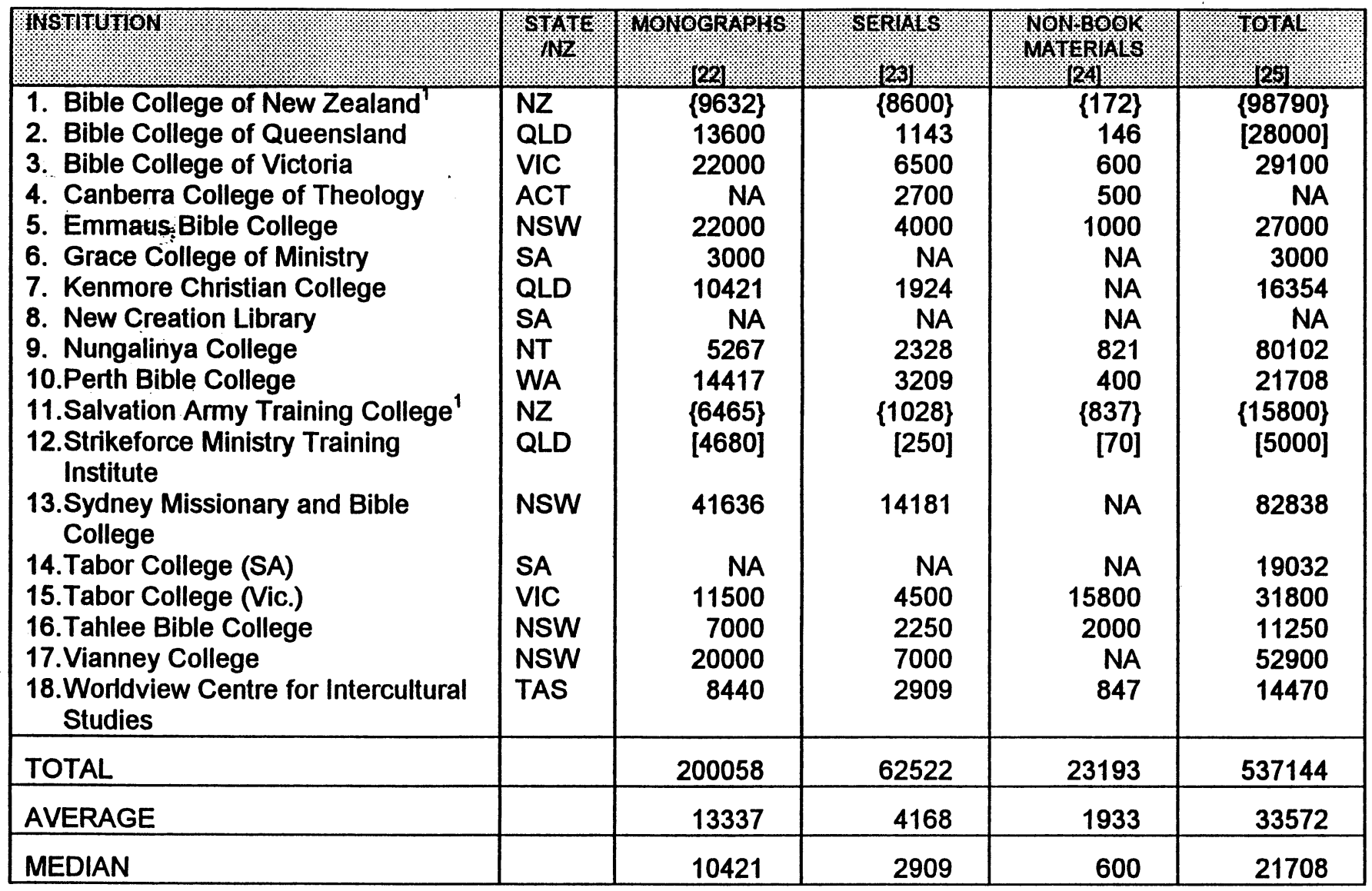

${ }^{1}$ Exchange rate $=0.86$ 
TABLE 4C 1997 LIBRARY EXPENDITURE

\begin{tabular}{|c|c|c|c|c|c|}
\hline INSTITUTION & STMTE. & MONOGRAPHS & SERIAIS & 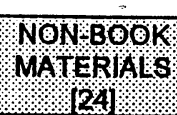 & TOTAL \\
\hline $\begin{array}{l}\text { 1. Carmelite Library } \\
\text { 2. Catholic Education Office } \\
\text { 3. Columban Mission Institute } \\
\text { 4. Diocesan Resource Centre } \\
\text { 5. Mollison Library } \\
\text { 6. New Norcia Library } \\
\text { 7. Rabbi Falk Library } \\
\text { 8. St. Benedict's Monastery }\end{array}$ & $\begin{array}{l}\text { VIC } \\
\text { QLD } \\
\text { NSW } \\
\text { SA } \\
\text { VIC } \\
\text { WA } \\
\text { NSW } \\
\text { NSW }\end{array}$ & $\begin{array}{r}\text { NA } \\
3441 \\
1997 \\
6500 \\
\text { NA } \\
7368 \\
\text { NA } \\
6844 \\
\end{array}$ & $\begin{array}{r}\text { NA } \\
860 \\
6607 \\
2550 \\
\text { NA } \\
3677 \\
\text { NA } \\
3295 \\
\end{array}$ & $\begin{array}{r}\text { NA } \\
1477 \\
0 \\
9620 \\
\text { NA } \\
2455 \\
\text { NA } \\
3750 \\
\end{array}$ & $\begin{array}{r}\mathrm{NA} \\
5945 \\
\mathrm{NA} \\
43243 \\
\mathrm{NA} \\
{[35000]} \\
\mathrm{NA} \\
13889 \\
\end{array}$ \\
\hline TOTAL & & 26150 & 16989 & 17302 & 98077 \\
\hline AVERAGE & & 5230 & 3398 & 3460 & 24519 \\
\hline MEDIAN & & 6500 & 3295 & 2455 & 13889 \\
\hline
\end{tabular}

TABLE 4D 1997 LIBRARY EXPENDITURE

\begin{tabular}{|c|c|c|c|c|c|}
\hline INSTITUTION & STATE & $\begin{array}{l}\text { MONOGRAPHS } \\
1221)\end{array}$ & SERIALS: & $\begin{array}{l}\text { NONBBOOK } \\
\text { MATERIALS } \\
\text { [24] }\end{array}$ & $\begin{array}{l}\text { TOTAL: } \\
255\end{array}$ \\
\hline $\begin{array}{l}\text { 1. Australian Catholic University - } \\
\text { McAuley Campus }\end{array}$ & & 60000 & 115000 & NA & 760000 \\
\hline $\begin{array}{l}\text { 2. Australian Catholic University - Mt. } \\
\text { St. Mary's Campus }\end{array}$ & NSW & 59057 & 59772 & 1 & 118829 \\
\hline $\begin{array}{l}\text { 3. Australian Catholic University - } \\
\text { Signadou Campus }\end{array}$ & ACT & 43889 & 43817 & NA & 87706 \\
\hline 4. Catholic Library of WA & WA & 17409 & 7735 & 25195 & 421424 \\
\hline TOTAL & & 180355 & 226324 & 25195 & 1387959 \\
\hline AVERAGE & & 45089 & 56581 & 25195 & 346990 \\
\hline MEDIAN & & 43889 & 43817 & 25195 & 118829 \\
\hline
\end{tabular}




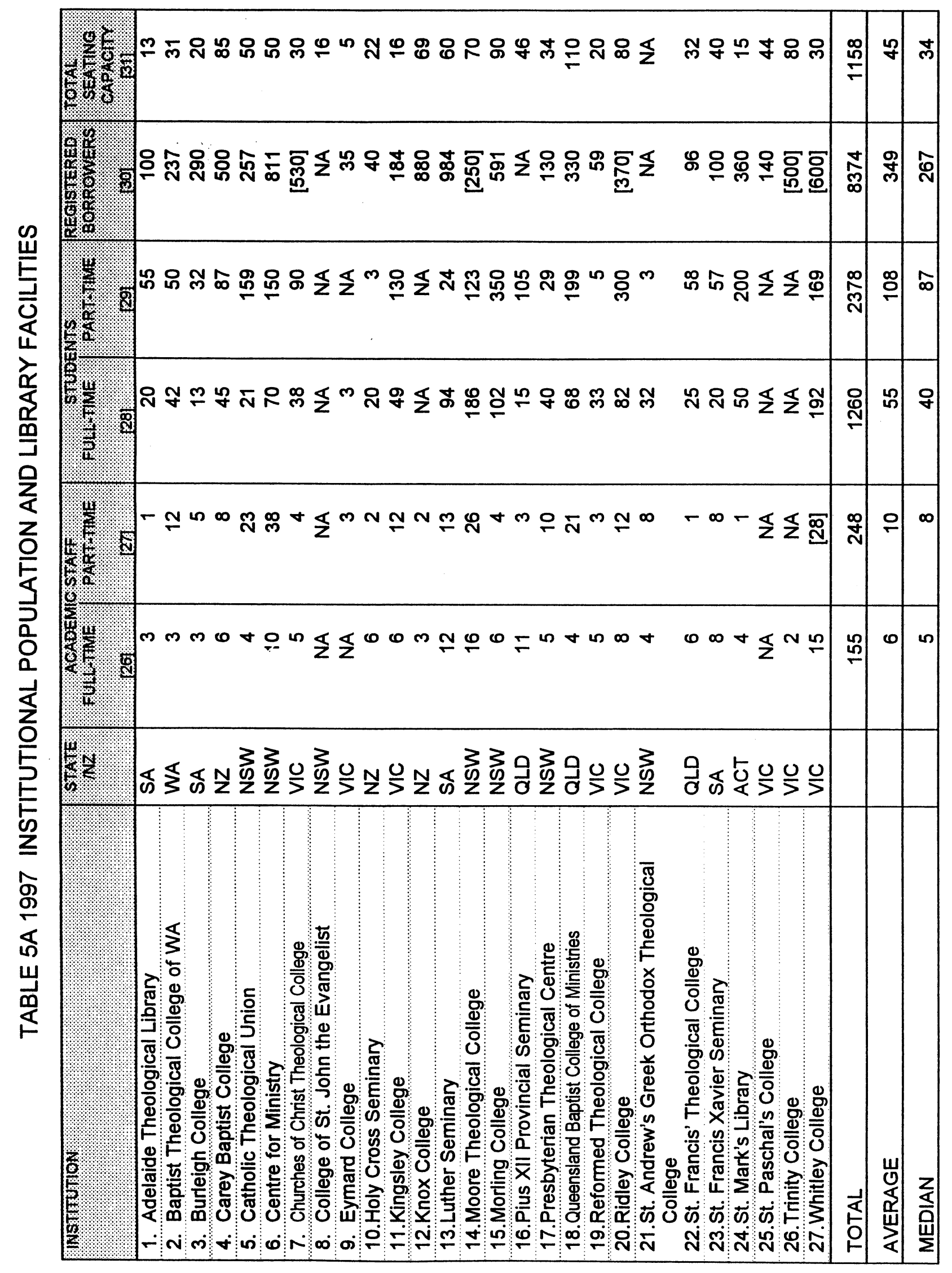




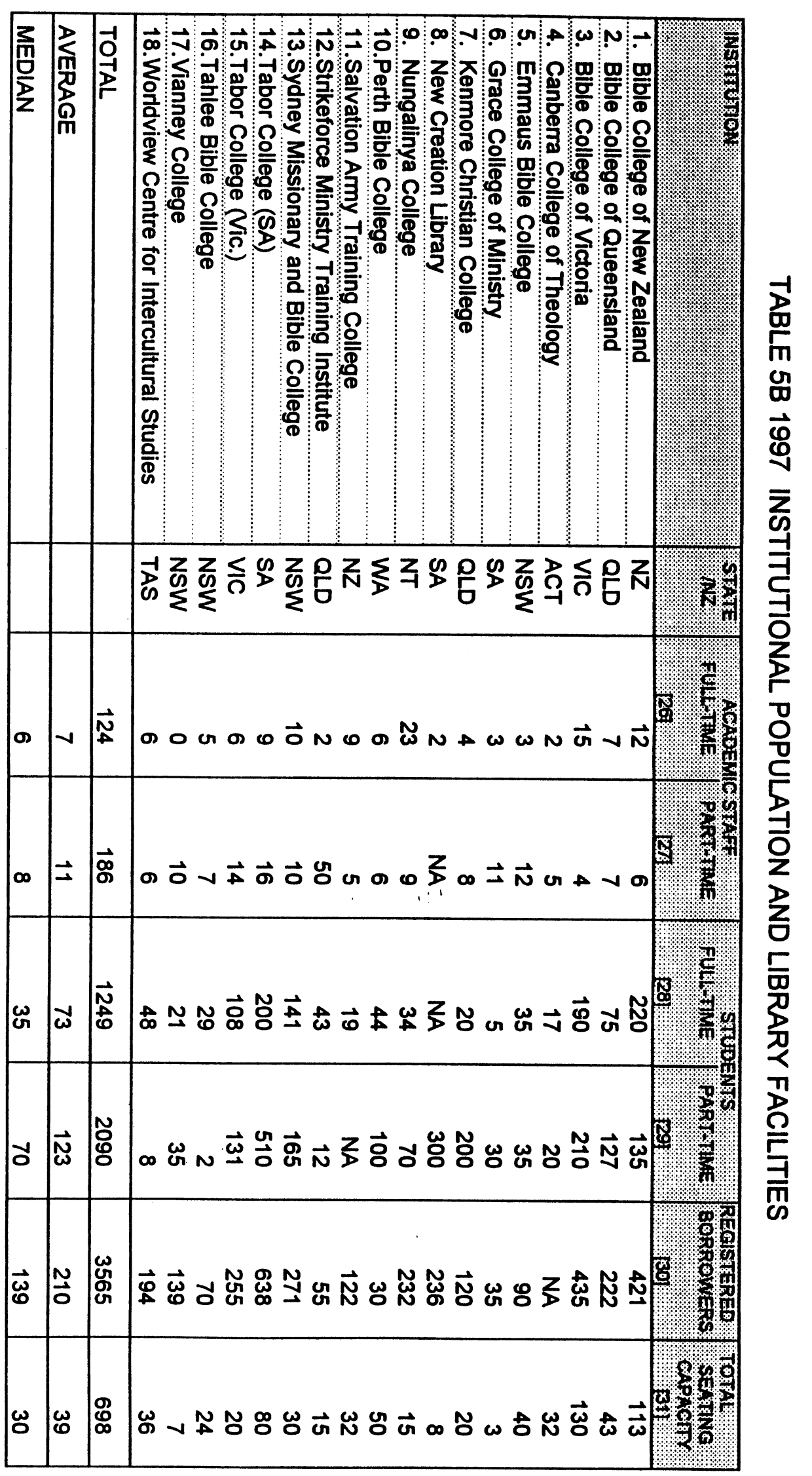



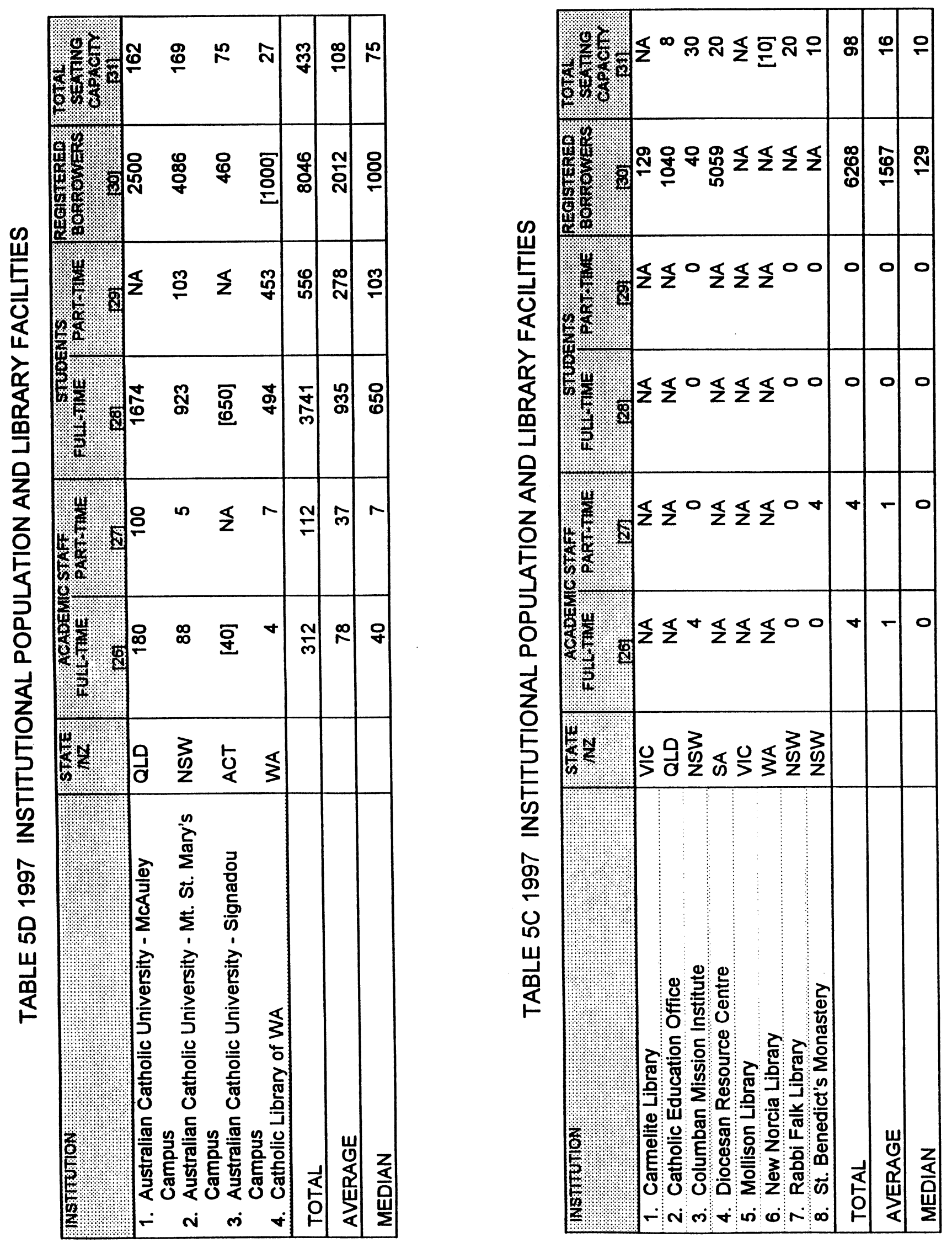


\title{
The division of the Gillespie Library
}

\author{
Catherine Halsall
}

The Theological Hall of the Presbyterian Church in New South Wales was established at St Andrew's College, University of Sydney in 1873. From the early 1920s the Church cooperated in theological education with the Methodist and Congregational Churches under the umbrella of the United Faculty of Theology. The Library of this institution was named in honour of Robert Gillespie, a prominent businessman and generous benefactor. Since the formation of the Uniting Church in 1977, separate denominational colleges have been established.

Principally, because of the times in which it was expanding and the men who influenced its collecting policy, the Gillespie Library demonstrated through its holdings the growth of the 19th century Higher Criticism movement; the development of liberal theology in the 20th century; and, the modern fascination with the relationship between philosophy and religion. Its background also ensured a fine source of Scottish church history.

After some years of debate over the future of the Library it was acknowledged, through an agreement with St Andrew's College, that the collection was jointly owned by the Presbyterian Church in N.S.W. and the Uniting Church in N.S.W. After retaining some archival records pertinent to the College itself, and noting that a number of rare books were on permanent loan to Fisher Library, St Andrew's concurred with the churches that the holdings were to be divided between the two churches in question.

Initially permission was sought and granted to divide the journal collection, one of the main reasons for this being the imminent revision of AULOTS and the consequent desire to have accurate location for these journals. In theory application for Interlibrary loans had been possible since 1990 but difficulties, mainly through lack of staff, often evolved. Three lists were drawn up - a proposed list for the Presbyterian Library; a proposed list for Camden Library (Uniting Church) and a list of journals "for discussion". The suggested criteria were as follows : if journals were held at one library and not the other, the holding Library was to have first opportunity to fill gaps; if journals were already held as a complete collection in one library, the other library was to take those available. Exceptions were to be made in that journals pertaining to Presbyterianism/ Scotland were to go to the Presbyterians; journals pertaining to Methodism/ Wesley/ Uniting Church were to go to the Uniting Church. Obviously the third list involved journals to which neither library had any type of prior claim and in which both libraries showed a definite interest.

A meeting was held between the two parties and agreement on division was reached quite amicably. The Presbyterian Librarian then went to the Gillespie Library and physically separated and packed her allocation which was then transported to Burwood for processing, both for the Library and for AULOTS. Camden Library elected to leave its journals to be collected when the books were divided but was able to update its listing for 
AULOTS by using the Gillespie records. This procedure took place late 1996 to early 1997.

The modus operandi for the division of the book collection was to be as follows:

(i) Uniting Church to inspect the catalogue of books and to nominate which books it would seek to acquire, being less than $50 \%$ of the books available.

(ii) Negotiations would be entered into between the two Churches on the basis of the list proposed by the Uniting Church, but not confined to that list, leading to mutual agreement on which books would be retained by one Church and which available to the other.

(iii) The balance of the books to become the property of the Presbyterian Church. After agreement the Presbyterian and Uniting Churches were to be at liberty to remove the books to become their respective property and to handle, store and otherwise dispose of them in accordance with normal library practice.

In July of 1997 the Camden Library transported the Gillespie catalogue drawers to North Parramatta for the purposes of thorough checking against its own holdings. There were two main catalogues - the earliest holdings under a fairly elementary unknown classification scheme; and, the more recent holdings classified by the Pettee scheme. A small selection of the latter group had been isolated, the books shelved alphabetically by author/editor and the catalogue cards filed separately. It was thought that this had been done due to the fact that, after a certain date, it could be clearly ascertained through financial records of trust monies which of these books belonged to a particular church. However this proposition for division had been abandoned. Thus in essence three lists had to be compiled. The Uniting Church was able to employ two qualified people to carry out the checking procedures and the resultant listings. One of these was the Librarian of the Presbyterian Centre (for 3 days a week) and this enabled some preliminary discussions to take place. Two volunteers were also engaged to help in initial checking and the refiling of catalogue cards. The collection had to be compared with holdings on both Computer and Card Catalogue. In addition the Library Manager and the Librarian of Camden Library, accompanied at various times by subject specialists from Faculty, visited the Gillespie Library to inspect works and establish which might be missing.

In September the lists were formerly handed over to the Presbyterians. Initially the Librarian checked the lists against the library holdings to eliminate the need to express interest in any works already held. Department heads were given copies of their subject areas for consultation and two members of faculty accompanied the Librarian to the Gillespie Library to ascertain the works which were not requested by Camden Library. Checking against these was randomly executed. As a result lists were prepared by the Presbyterian Librarian consisting of works in which both libraries were now expressing an interest. Eventually in October a meeting was held, attended by representatives of both Colleges, to discuss a proposal for division which had been drawn up by the Principal of the Presbyterian Theological Centre. 
In the field of basic principles it was recognised that each library should build its collection in the area of its relative strength and the particular interests and respective theological ethos of each college. It was agreed that both libraries would be accessible to students and staff from both colleges, with borrowing rights to be extended to the staff from both colleges. It was also resolved that the catalogue cards would be divided so that both libraries would have a complete record of the Gillespie collection and the subsequent location of each work. It was agreed that a pamphlet box would equal a book for the ease of division. Where it occurred that both libraries were particularly interested in a specific pamphlet one library would take a photocopy of same. If photocopying could be too involved then negotiations would have to be made.

The following categories were accepted:

- Category A : Those books where there were duplicate copies held at Gillespie.

- Category B : Those books which one college would like and in which the other expressed no interest.

- Category $\mathrm{C}$ : Those books in which both libraries expressed an interest but one library already held a copy.

- Category D : Those books in which both libraries expressed an interest and no copy was currently held by either library.

- Category E : The residue after all of the above. This included some duplicates for both libraries or some material of secondary interest.

The different steps of the proposal were then considered:

Step 1 : Books in Category A were to be divided equally (whether or not they were on the UTC listing). If one library wanted duplicate copies after the other steps had been taken, and the other library was agreeable, this could be negotiated. The duplicates represented nearly $15 \%$ of the Gillespie collection. In this regard it was agreed that duplicates would be equally shared and where there was an odd number of duplicates Category E would apply.

Step 2 : Books in Category B for which Camden Library expressed an interest were to go to Camden. This represented about 5,500 books or approximately $70 \%$ of the Camden listings. Approval was given for Step 2 to proceed.

Step 3 : The library not already holding a copy was to have first option on any books already held by the other (Category C). Approval was given for Step 3 to proceed.

Step 4 : Books in Category D were to be divided equally between the two libraries. Rather than a book by book approach, it was proposed that the two libraries attempt to reach an agreement on some broad category divisions. Based on the patterns observed in the lists prepared and considering the theological ethos of each college an inital suggestion was as follows:

- Camden was to have first option on all (jointly desired) books on Biblical Studies in the areas of Genesis, Psalms and Luke/Acts; General Philosophy; Philosophy of Religion; Contemporary Theology; Ecumenical Movement; World Religions (except Judaism); Comparative Religion; Social Sciences; 
Ethics; Education; Contemporary Liturgy (except specifically Presbyterian material); Pastoral Theology and Preaching (except material relating specifically to Presbyterianism); General Literature; Encyclopaedias (i.e. sets classed at $Z$ in the earlier collection).

- The Presbyterian Library was to have first option on all (jointly desired) books on Biblical Studies (except Genesis, Psalms and Luke/Acts); Biblical and Cognate Languages; Classical Protestant and Reformed/Presbyterian Theology, Worship, History and Polity; Judaism; Patristics; History; Liturgical Studies (historical material).

Any books in Category D not covered by agreed categories were to be split on a batch by batch or book by book basis. (Small subject areas which eventually fell into this grouping and were divided book by book were Church Architecture and Missiology). Step 4 involved discussion. The Camden Library agreed to the proposal for the division of books in Category D with one reservation. This was the field of Patristics. It was therefore decided to arrange a meeting of Patristics representative from each College and the books in question would be divided on a book by book basis.

The Presbyterians also held one reservation in the division of books in this category. It was consequently agreed that it would express no further interest in works in the field of General Philosophy on the provision that it was awarded all works in the series: Library of Living Philosophers / edited by Schilpp.

Step 5 : The Presbyterians were to select an equal number of books under Category B (to equal the number taken by Camden under Category B)

Step 6 : Any remaining books to be divided equally. Because the Uniting College had the initiative in the first tranche, it was proposed that the Presbyterian Centre be given first option on this residual material (to $50 \%$ ).

It was resolved that the Presbyterians carry out Steps 5 and 6. Because of the preliminary work done on checking and listing by Camden, the Presbyterians assented to carry out the initial work of physically separating the Gillespie collection on the above formula keeping the books within the Gillespie room. After representatives from Camden Library had expressed their satisfaction with the division the books could be transported to their new locations.

After this agreement was finalised the Presbyterian Librarian, with the Principal and another member of faculty, spent early November in the Gillespie Library physically separating the books to the arrangement and checking Category E books against library holdings on the computer. Meanwhile permission had been gained from St Andrew's College to acquire the book-shelving on an equal basis. It had also been decided that as soon as the Uniting College approved the division the Presbyterians would be removing their allocation immediately. Consequently the shelving which was most accessible for first removal was assigned to the Presbyterians and books were stacked appropriately. 
In both cases the Colleges co-opted students and staff to do the packing. Book boxes, tape, scissors, labels, etc. were purchased where necessary and the different categories packed separately. The Presbyterians also had the help of students in the actual dismantling of shelving and the transportation of books and shelves. The bulk was carried out in one day but it was necessary to make two or three trips in the following week to collect the residue. The Uniting Church chose to employ a professional removalist and their books were taken to a Fumigation Company before transportation to North Parramatta.

Preparation had been made at both Colleges for the Gillespie arrival. At Burwood building extensions had been carried out in the twelve months before primarily to expand the library. There was therefore a room specifically set aside for the Gillespie Library. Shelving was thoroughly scrubbed and reassembled during the holiday period of January 1998. At the beginning of semester students were again co-opted, this time to unpack! Books were filed in two sequences - the Old system from one end and the Pettee collection from the other. A stocktake is to be carried out and the appropriate catalogue cards filed so that the collection will still be accessible whilst awaiting processing. At North Parramatta shelving and books were accommodated in two of the Library rooms and in the downstairs stack.

The acquisition of the Gillespie books has greatly enhanced the collections of both the Uniting Church Centre for Ministry and the Presbyterian Theological Centre. It is tremendous that this collection will once again be extensively used but the challenge of processing is quite awesome given that the normal day to day running of both libraries is most time consuming (but nevertheless always rewarding).

Catherine N. Halsall

\section{A valuable addition to your library's collection}

Violating trust: professional sexual abuse. Proceedings of the First Australian and New Zealand Conference on Sexual Exploitation by Health Professionals, Psychotherapists and Clergy.

Sexual misconduct and exploitation by clergy is increasingly recognised as a major problem in pastoral settings. This work contains contributions from major overseas and Australian commentators, including Rev. Marie Fortune, Prof. Patrick Parkinson and Dr Neil Ormerod, as well as contributions from survivors of abuse and exploitation. Contributions also cover exploitation by health professionals, counsellors and therapists, and strong parallels are drawn between the effects of abuse in these various settings. Legal issues are also investigated.

This book is a significant contribution to concerns in Pastoral Theology and a valuable addition to theological libraries.

Cost : $\$ 75.00$ plus $\$ 7.50$ postage. Available from CAHPACA Inc. PO Box 674, Rozelle NSW

2039. Cheque payable to CAHPACA Inc.

Contributed by Anne Hocking 


\section{New Norcia and Freedom of Information}

Everyone has the right to freedom of opinion and expression: this right includes freedom to hold opinions without interference and to seek, receive and impart information and ideas through any media regardless of frontiers.

Article 19 of the Universal Declaration of Human Rights (1948)

In the fiftieth anniversary year of the Universal Declaration of Human rights, the annual New Norcia Library Lecture was a passionate plea of a librarian to support Article 19. The lecturer was Alex Byrne, who chairs the Committee on Free access to information and Freedom of Expression within the International Federation of Library Associations and Institutions (IFLA):

His concluding words were :

In an increasingly interconnected world, information is more than ever crucial. The human right to freedom of expression and free access to information is the foundation of autonomy, both individual and societal. Librarians must defend that right vigorously, ensuring that it is not compromised nor abrogated. While taking a duty of care when appropriate and taking steps to respect individual cultures and individual preferences, we must stand for freedom, in both expression and access to information.

As Pro Vice-Chancellor (Information Resources) of the Northern Territory University, Alex also spoke of providing information to Aboriginal and Torres Strait Islander peoples. He has developed protocols in consultation with them about information which is culturally sensitive.

The New Norcia Library Lecture, held in the monastic town of New Norcia, 132 miles north of Perth, is popular with public librarians, librarians from universities and Information Studies students. The lecture, always informative and often provocative, is followed by a large lunch and concludes with a lively panel discussion. Librarians drive up from Perth for the day, enjoying the spring wildflowers en route, and can visit the museum, art gallery or archives while in the town.

In 1999, New Norcia will be privileged to have the library lecture delivered by Father Leonard Boyle from Rome, who, as Vatican Librarian, embarked on a modernisation programme which included the digitisation of many thousands of documents from the peerless collection in the Vatican Library. The lecture is scheduled for September 16.

\section{Susan Johnson}

See Alex Byrne's own account of his lecture : "National Front demands access to right-wing material, Bishop burns books" in Incite v.19, no.11 (Nov 1998) p.8-9. 


\section{Notes from the MCD}

The libraries of the Melbourne College of Divinity are jointly undertaking a Conspectus of their collections. The project started in September 1998. By the end of April, most libraries will have completed the bulk of the work they will have to do.

There are a total of fifteen libraries belonging or connected to the four Associated Teaching Institutions of the MCD : Queen's College Library, Trinity College's Mollison Library, and the Joint Theological Library at the United Faculty of Theology; Whitley College Library and the Churches of Christ Theological College Library at the Evangelical Theological Association; the libraries of the nine member colleges and seminaries of the Yarra Theological Union: the Holy Cross Retreat, the Redemptorist Seminary, the Carmelite Theological College, the Discalced Carmelite Monastery, St Dominic's Priory, St Vincent Pallotti College, Eymard College, Dorish Maru College and St Paschal's College; and the library of Corpus Christi College at the Catholic Theological College. Eleven of these libraries are involved in the present exercise.

We are undertaking an evaluation of our collections in order to make important information about our collections available to the students and staff of the MCD, and to one another. We are using Conspectus methodology because doing so will enable us to publish our results more widely. It is possible that new forms of co-operation among us will arise from the exercise, but we are not undertaking the Conspectus for this reason. We are doing it now, because we obtained a grant from the MCD to help us to organise it, and to cover the expenses of the poorer libraries. We are grateful to the MCD for this support.

The first stage was the holding a workshop to which we invited representatives of each MCD library. The aims of this workshop were to explain what Conspectus was all about, and how it could benefit individual libraries and their users; to provide libraries considering whether to take part with a realistic idea of what would be involved; and to explain the techniques of doing a Conspectus. We also wanted to provide a forum for discussion of some of the guidelines that would have to be laid down on such matters as choice of checklists. And we felt that a forum was necessary to launch the project and attract the commitment of members of the group to participate in it.

In the second stage, which is presently underway, each library is struggling to complete a two part report on its collections and list its periodicals and standing orders. The first part of the report is an overview of the library's collection based on a cluster of subheadings decided at the workshop. In the second part the collection is assessed, subject by subject, using the objective techniques of evaluation and description endorsed by Conspectus methodology. The deadline for our individual work is the end of April. We are hopeful at this stage that most of us will be able to meet this deadline.

The group is fortunate in having attracted Dr Lawrence McIntosh to accept appointment as Consultant to the project. To date this role has involved Lawrence in organising and leading the workshop, and in giving a day of his time to each of many libraries to help 
them with problems or support them through the next steps. His contribution has been highly valued by every member of the group.

Later, in the third stage of the exercise, we will be working on the publication of our results. We are hopeful we will be able to produce a book which can be sold to anyone interested. We will also consider use of the Australian Libraries Gateway.

Stephen Connelly

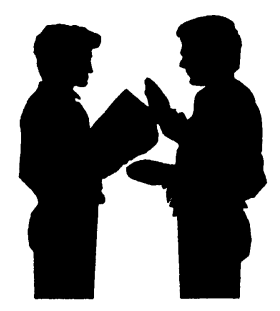

\section{ANZTLA-forum}

ANZTLA-forum is an email discussion list which aims to bring ANZTLA members closer together. If you are a personal member of ANZTLA or an employee of an ANZTLA member institution you are able to become a member of the list.

To subscribe start your email programme and fill in the screen as follows:

To : majordomo@ormond.unimelb.edu.au

Subject : $\quad$ subscribe ANZTLA-forum [your email address]

Notes : 1 . Leave the subject field empty.

2. The case you use in entering the name of the discussion list is unimportant.

3. Include an email address in the message only if it is different from the one you use when you subscribe and you want correspondence from ANZTLA-forum to go there.

4. Turn off the option in your email programme that automatically adds your signature to outgoing messages, if you have it.

Having subscribed to ANZTLA-forum, you will want to send messages to it. The address to use is : ANZTLA-forum@ormond.unimelb.edu.au

Stephen Connelly

Joint Theological Library

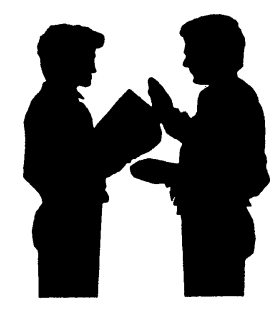




\section{ANZTLA Standards : update}

It was agreed at the 1997 AGM, that Jocelyn Morris and Wendy Davis should coordinate the updating and revision of the ANZTLA Standards (1988). Chapters were asked to discuss the Standards and make suggestions as to amendments.

During 1988 most Chapters have done this and passed their results on to Jocelyn and me. We now have a document (Draft Standards, version 2 - 20/11/98) incorporating the proposed amendments. This document has been sent back to Chapters for further discussion.

We hope that Chapters will take the time to review this document and comment on the proposed amendments.

It may seem that this work is tedious, however it is valuable in the long term. It is important that all Chapters fully discuss these matters, and that opportunity be given for all points of view and useful suggestions to be considered. The final document will then be a document that is 'owned' by ANZTLA people, and we will each have a much better understanding of the purpose and contents of the Standards. Any issue which causes people to think about the deeper issues of their activities (how, when, why we do what we do) is constructive.

We hope at least to have items for discussion at the ADELAIDE conference. Whether or not we are up to the voting stage will depend on the discussion in Chapters.

Wendy Davis

\section{Gleanings from ABTAPL bulletin November 1998}

- Check out ABTAPL's website at : www.newman.ac.uk/abtapl/home.html

- News of a 1998 edition of Union list of periodicals (in British theological and philosophical libraries), edited by Evelyn Cornell, King's College Library, London.

- Main articles : Report on the $27^{\text {th }}$ General Assembly of the International Council of Theological Library Associations, 1998 (Conseil)

"Partners with Europe" by Andre Geuns and Penelope Hall - a joint presentation from the Conseil Assembly;

"Library collaboration in a regional and national context: a view from higher education" by Clive Field, Librarian and Director of Information Services at the University of Birmingham.

Enquiries should be directed to abtapl@mailbase.ac.uk 
Have you heard about the proposed European Partnership for Subject Gateway on Religion

Readers may have received a message recently via ANZTLA-forum which outline a proposal for coordinating a European consortium of institutions for the purpose of creating a subject gateway on religion. The email originated from Torill Redse, of the Faculty of Theology, University of Oslo, Norway.

The gateway, aimed at all age groups, will provide an online learning space for open and distant learning. A key element being resource discovery and metadata encoding based on DublinCore and RDF/XML. Some issues needing to be addressed are : Metadata standard, resource directory, data storage, design and usability, and rights management, and not least : the creation of a new browsable subject classification scheme for online resources on religion.

Those proposing the project are looking for prospective partners within the library sector. If you are interested in more information about this proposal, and on the issue of creating a new classification scheme, see this Website : www.tf.uoi.no or contact : Forstekonsulent Torill Redse

RBT-Riksbibliotektjenesten

National Office for Research Documentation

Academic and Special Libraries

PO Box 8046 Dep.

N-0030 OSLO

NORWAY

\section{A Medieval Curse}

For him that stealeth a book from this library, let it change into a serpent and rend him. Let him be struck by palsy and all his members blasted. Let him languish in pain, crying aloud for mercy, and let there be no surcease for his agony until he sink to dissolution. Let book-worms gnaw his entrails in token of the worm that dieth not, and when at last he goeth to his final punishment let the flames of hell consume him, for ever and aye.

From the monastery of San Pedro, Barcelona. 